\title{
An Urgence To Establishing Regulations For Implementing State Administrative Justice Law
}

\author{
Sri Rahayu*) and Siti Rodhiyah Dwi Istinah ${ }^{* *}$ \\ ${ }^{*}$ Legislative Designer at the Regional Office of Ministry of Law and Human Rights, \\ Central Java, E-mail: ayudi3213@gmail.com \\ $\left.{ }^{* * *}\right)$ Faculty of Law, Universitas Islam Sultan Agung Semarang
}

\begin{abstract}
This study aims to examine and analyze why an implementing regulation is needed for Act No. 51 of 2009 concerning the Second Amendment to Act No. 5 of 1986 concerning the State Administrative Court. The research method used is descriptive qualitative research with a normative juridical approach that examines theories, legal principles and related legislation. The method of data collection was carried out by library research with the type of research data consisting of primary, secondary, and tertiary legal materials. The government needs to immediately establish implementing regulations for the State Administrative Court Law to provide legal certainty for the community,

Keywords: State Administrative Court; Implementing Regulations; Forced Effort.
\end{abstract}

\section{Introduction}

State Administration is a state administration that carries out the function to carry out government affairs both at the center and in the regions ${ }^{1}$. In carrying out these administrative tasks, there are possibilities that the government can do things that are harmed or violate the rights of citizens so that conflicts, disputes or disputes can arise between the State Administration Agency or Official and citizens of the community which can harm or hinder the course of national development. To anticipate disputes, then a Court that has absolute competence, especially those whose bodies are the State Administrative Court or State Administrative Court which is able to issue justice, truth, order and legal certainty so as to be able to provide protection to the community, especially in the relationship between the Official Administration Agency or State and the community. ${ }^{2}$

The establishment of the State Administrative Court is intended to resolve disputes between the government and citizens. With the existence of the State Administrative Court or the so-called PTUN which provides protection to the people with guarantees that can be obtained in accordance with the provisions of the legislation. In addition, the PTUN is intended to uphold justice, truth, order, and legal certainty, so that it can provide protection to the community, especially in the relationship between the State Administration Agency or Official with the community. ${ }^{3}$

This provision regarding the State Administrative Court is regulated in Act No. 5 of 1986 concerning the State Administrative Court, which was later amended

\footnotetext{
${ }^{1}$ Article 1 of Act No. 5 of 1986 concerning the State Administrative Court.

${ }^{2}$ Hasto Sasmito, Implementation Of Decisions And Obstacles Administrative Court Implementation Obstacles, Jurnal Daulat Hukum Unissula, Vol. 1. No. 2 June 2018, p. 2.

${ }^{3}$ Provisions Considering letter (d) of Act No. 5 of 1986 concerning State Administrative Courts.
} 
by Act No. 9 of 2004 concerning Amendments to Act No. 5 of 1986 concerning the State Administrative Court, and last amended by Act No. 51 of 2009 concerning the second amendment of Act No. 5 of 1986 concerning the State Administrative Court.

With the enactment of Act No. 9 of 2004 and Act No. 51 of 2009 has had executable power. This is due to the existence of norms regarding the existence of sanctions in the form of forced money and/or administrative sanctions, as well as publications against officials who do not carry out court decisions. But then there are obstacles in the implementation of these coercive efforts. Some of the things that become obstacles at the level of implementation of the coercive measure include the absence of a legal product under the law that regulates the mechanism of this coercion, what types of administrative sanctions can be imposed on defendants who are reluctant to implement the PTUN decision, and against whom the coercion pays (dwangsom) will be charged.

In the Administrative Court Law itself, it is stated that the provisions regarding the amount of forced money, types of administrative sanctions, and procedures for the implementation of forced payment and/or administrative sanctions are regulated by laws and regulations. ${ }^{4}$. However, since the enactment of Act No. 51 of 2009 concerning the second Amendment to Act No. 5 of 1986 concerning the State Administrative Court, there is no legal product that regulates the implementation of the Act comprehensively.

The existence of legal products as implementing regulations of the Administrative Court Law is in accordance with the order of laws and regulations that are often associated with Hans Kelsen's teachings on Stuffenbau des Recht or The Hierarchy of Law. Hans Kelsen argues that legal norms are tiered and layered in a hierarchy (organization), in the sense that a lower norm applies sourced and based on higher norms, higher norms apply sourced and based on norms. higher, and so on until a norm that cannot be traced further and is hypothetical and fictitious, namely the basic norm (Grundnorm ${ }^{5}$ ). Hans Kelsen's theory was developed by Hans Nawiasky in his book Allgemeine Rechtslehre. He argues that according to Hans Kelsen's theory, a legal norm from any country is always layered and tiered, where the lower norm applies, is based on, and originates from a higher norm, the higher norm applies, is based on, and is sourced from even higher norms, until a higher norm is called the Basic Norm ${ }^{6}$.

By analyzing the legal theory associated with the establishment of implementing regulations from the Administrative Court Law, the author is interested in analyzing the urgency of establishing implementing regulations for the Administrative Court Law regarding the coercive efforts of the Administrative Court decision. The purpose of this study is to examine and analyze why there is a need for implementing regulations for Act No. 51 of 2009 concerning the Second Amendment to Act No. 5 of 1986 concerning State Administrative Courts, especially related to coercive measures against the Administrative Court decision

\footnotetext{
${ }^{4}$ Article 116 paragraph (7) of Act No. 51 of 2009 concerning the Second Amendment to Act No. 5 of 1986 concerning State Administrative Courts.

5 Jimly Asshidiqie, Pengantar Ilmu Hukum Tata Negara (Jilid 1), Sekretariat Jenderal dan Kepaniteraan MK RI, Jakarta, 2006, p. 42.

${ }^{6}$ Maria Farida Indrati Soeprapto, Ilmu Perundang-Undangan: Jenis, Fungsi, dan Materi Muatan . (Yogyakarta: Kanisius), 2007, p. 44.
} 
and how the implementing regulations of the Act The PTUN is ideal for implementing the provisions of the Administrative Court Law.

\section{Research Method}

The approach method used in this research uses 3 (three) aspects, namely the statutory approach, analytical approach, concept approach. The research specifications used are descriptive-analytical, namely by describing the applicable laws and regulations related to legal theories and positive law implementation practices related to problems. ${ }^{7}$.

The data collection method used in this research is a literature study with a literature review of the library and the collection of books, written materials and references relevant to this research. The materials collected consist of primary, secondary, and tertiary legal materials. The data analysis method used in this research is descriptive qualitative analysis. Qualitative descriptive analysis begins with collecting data related to research, which is processed systematically.

\section{Results and Discussion}

\subsection{The Urgency of Establishing Implementing Regulations of the Administrative Court Law}

The implementation of government affairs in a legal state is based on laws and regulations in accordance with the principles adopted in a legal state, namely the principle of legality. However, because the legislation contains shortcomings and weaknesses, the existence of policy regulations as an instrument of state administrative law occupies an important position, especially in a modern legal state. ${ }^{8}$ Based on the legal system in Indonesia, statutory regulations according to their basic authority can be classified into statutory regulations that have the attribution authority of the Constitution or the Act, and there are statutory regulations whose function is to carry out orders or delegation of regulations. above it delegates it.

The source of delegation's authority in laws and regulations gives birth to products of legislation which are often referred to as Implementing Regulations. Implementing Regulations are regulations that function as implementing laws or what is referred to as "delegated legislations" as "subordinate legislations". Referred to as "delegated legislations" because the authority to determine it comes from the delegated authority of the law by the legislature. ${ }^{9}$

Implementing Regulations referred to here are rules made by the executive (government) or other bodies in order to implement the law. In contrast to making laws, implementing regulations are made without involving the legislative body (DPR). In various countries, the terms used include delegated legislation,

\footnotetext{
${ }^{7}$ Ronny Haniatjo Soemitro, Metode Penelitian Hukum dan Jurumetri, (Jakarta: PT Ghalia Indonesia, 1990), p. 97-98

${ }^{8}$ Jawade Hafidz, Malfungsi Han Dan Upaya Melakukan Rekonstruksi Sistem Hukum Yang Ada Menuju Hukum Yang Melayani. Jurnal Hukum Unissula, Vol. XXVIII, No.2 December 2012, p. 9.

${ }^{9}$ Jimly Asshiddiqie, Perihal Undang-Undang, Ed.1, Konstitusi Press, Jakarta, 2006, p. 275.
} 
subordinate legislation, secondary legislation, subsidiary legislation, legislative instruments, or statutory instruments.

Delegating the making of implementing regulations to the executive process is faster because it does not require a protracted debate in the DPR. DPR's time will be taken up to discuss details. Often urgent and immediate arrangements are required. Delegation of making implementing regulations has several benefits, namely avoiding one branch of power (executive or legislative) from dominating the power so that it does not create the principle of checks and balances of power. If implementing regulations are dominated by the legislature, in the sense that implementing regulations are made by the legislature, it can practically impede the implementation of a law by the executive considering that the legislature does not know the detailed implementation practices and local regulations. On the other hand, if the implementing regulations are made in full by the executive, then the legislative power will potentially be taken over by the executive. In addition, it prevents the executive from running the government uncontrollably. The existence of a delegation of authority from the legislature to the executive will prevent the executive from improvising inappropriately in administering the government ${ }^{10}$.

In the formation of implementing regulations, it can be in the form of Government Regulations, Presidential Regulations, Regional Regulations, Ministerial Regulations, Regulations of Head of Institutions. In accordance with the hierarchy of laws and regulations in Act No. 12 of 2011 concerning the Establishment of Legislations, regulations that are under the position of Law are Government Regulations ${ }^{11}$. As for the content of this Government Regulation, it contains material for carrying out the Act as it should 12 .

The essential element for realizing law enforcement is obtaining legal certainty, justice and benefits from law enforcement. The law enforcement process can run effectively if it is a chain of several processes that cannot be separated ${ }^{13}$.

Basically, the execution of court decisions is a series of all procedural legal processes that are tangible in the form of coercive law carried out by the court against the party who is declared defeated in a case. This process is a continuous action of the entire procedural law process. Execution is an integral part of the implementation of procedural rules. Execution or execution of a decision is an act carried out by force against the losing party in a case, not willing to voluntarily fulfill or carry out an order or court decision that has permanent legal force. Execution becomes unnecessary when the defeated party is willing to fulfill an order or court decision with permanent legal force voluntarily. In such a situation, if the defeated party is the defendant, then his position in the execution process becomes "the respondent is executed". Meanwhile, if the losing party in the case is the plaintiff, usually even logically, there is no decision that needs to be executed.

\footnotetext{
10Sucipto, Purnomo. Mengapa Undang-Undang perlu peraturan pelaksana. https://setkab.go.id/mengapa-undang-undang-perlu-peraturan-pelaksanaan/. 11 March 2015. Retrieved 01 July 2021.

${ }^{11}$ Article 7 of Act No. 12 of 2011 concerning the Establishment of Legislation.

${ }^{12}$ Article 12 of Act No. 12 of 2011 concerning the Establishment of Legislation.

${ }^{13}$ Alvi Syahri. Penegakan Hukum Terhadap Kebijakan Yang Melanggar Kode Etik. Jurnal Daulat Hukum Unissula. Volume 3 Issue 3, 2020, p. 6.
} 
This is in accordance with the nature of the dispute and the status of the parties in a case ${ }^{14}$.

In Article 116 paragraphs (4) and (5) of Act No. 9 of 2004 concerning Amendments to Act No. 5 of 1986 concerning State Administrative Courts, it is stated that "In the event that the defendant does not implement a court decision that has permanent legal force, the official concerned is subject to coercive measures in the form of payment of a certain amount of forced money and/or administrative sanctions" and "The official who does not carry out the court decision as referred to in paragraph (4) is announced in the local printed mass media by the clerk since the provisions as referred to in paragraph (4) are not fulfilled. 3) ".

The mechanism for applying forced money related to the execution of the TUN Court's decision in practice still raises problems, namely to whom is the forced money (dwangsom) charged? Is it on the finances of the relevant TUN official agency or on the finances/personal assets of the relevant TUN official (defendant) who does not want to implement the TUN Court decision. Likewise, how much money must be paid by the defendant who does not want to obey the TUN court decision? This issue is not explicitly specified in Act No. 9 of 2004. The absence of rules that clearly regulate the imposition and amount of forced money on state administration officials who do not voluntarily carry out the TUN Court's decision is a legal obstacle that arises in the practice of the TUN Court in relation to the execution of the TUN Court's decision. The urgency of coercive measures is as a guarantor of legal certainty as a general principle of proper governance, namely a state of law that prioritizes the basis of legislation, propriety and justice in every policy of state administrators. ${ }^{15}$. Even this effort through forced money is not related to the substance of the disputed problem because basically the final goal of the dispute submitted to the TUN Court is a change to the policy issued by the TUN official which is considered detrimental to other individuals or communities, not as compensation as in a dispute civil law in general. Understanding the difficulty of implementing the TUN court decision, a second amendment was made to the Administrative Court Law through Act No. 51 of 2009 concerning the Second Amendment to the Administrative Court Law, especially in Article 116.

The provisions mentioned above indicate that there are additions to the mechanisms and stages that can be followed if the TUN officials do not carry out the TUN court decisions voluntarily, but the provisions above again cause problems, because they are not clearly stated in the provisions of the law or other regulations that more about the implementation of announcements through the mass media and to whom the fees must be paid? Furthermore, in addition to announcements in the mass media, the head of the court must submit this to the President as the holder of the highest government power to instruct the official to carry out the court's decision, and to the people's representative institution to carry out the supervisory function. This kind of procedure, of course, creates problems because it can be predicted that this kind of procedure will take quite a

\footnotetext{
${ }^{14}$ M. Yahya Harahap, Ruang Lingkup Permasalahan Eksekusi Bidang Perdata, Sinar Grafika, Second Edition, Fourth Printing, Jakarta, 2009, p. 6.

${ }^{15}$ Ridwan Hr, Hukum Administrasi Negara, Raja Grafindo Persada, Jakarta: 2007, p.254.
} 
long time and be convoluted to the point where we have to wait for the President's order. And if the Chief Justice submits a report to the President and the President does not take any action, or remains silent, what should he do? This is a separate issue that is no less complicated.

The absence of implementing regulations governing the execution and administrative sanctions of the decisions of the State Administrative Court, since the ratification of the amendment to the State Administration Law in 2009 which means that it has been almost 12 years since this Law has been implemented without any implementing regulations, of course results in unclear procedures implementation of administrative sanctions and creates a legal vacuum in the implementation of the decisions of the State Administrative Court. The existence of a legal vacuum that is long enough will be very detrimental to justice seekers (yustisiabellen) who have been declared winners or their claims are granted at the State Administrative Court (PTUN). In addition, there are implementing regulations of the PTUN Law as a guarantor of legal certainty as a general principle of proper governance, namely a state of law that prioritizes the basis of legislation, propriety and justice in every policy of state administrators.

Therefore, it is important to immediately draw up implementing regulations from the Administrative Court Law related to the implementation of this forced effort. It is hoped that the institution in accordance with its field of duty, in this case the Supreme Court, can prepare a draft implementing regulation of the Administrative Court Law, so as to create legal certainty in the community.

\subsection{The idea of an ideal Implementing Regulation as an implementing regulation of the Administrative Court Law}

Talking about ideals means relating to everyone's point of view. In this case, the author tries to give the idea of an ideal implementing regulation as the implementing regulation of the Administrative Court Law. This idea is based on the theory and hierarchy of laws and regulations.

As a state of law, all aspects of life in the fields of society, nationality, and the state, including government, must be based on laws that are in accordance with the national legal system. The national legal system is the law that applies in Indonesia with all its elements that support each other in anticipating and overcoming problems that arise in everyday life. One of the elements in the national legal system is the system of laws and regulations which is also a very important aspect in the administration of government. The legal system in principle must be based on statutory regulations and not based on instantaneous decisions for certain matters (ad hoc). ${ }^{16}$.

In accordance with the hierarchy of laws and regulations in Act No. 12 of 2011 concerning the Establishment of Legislation, that the content material is under the Law/Government Regulation in Lieu of Law. The content of the Government Regulation contains material for carrying out the Act properly ${ }^{17}$. So in

\footnotetext{
16Bayu Dwi Anggono, Perkembangan Pembentukan Undang-Undang di Indonesia (Jakarta: Konstitusi Pers, 2014). Bayu Dwi Anggono quotes Achmad Ali's writings in his book Menguak Teori Hukum (Legal Theory) dam Teori Peradilan (Judicial prudence), 2009, p. 186.

17 Article 12 of Act No. 12 of 2011 concerning the Establishment of Legislation.
} 
this case, the author assumes that the most appropriate regulation as the implementing regulation of the PTUN Law is a Government Regulation.

According to Prof. A. Hamid S. Attamimi ${ }^{18}$, Government Regulations cannot be formed without first having a law that becomes the 'parent'. In order to implement, describe, or detail the provisions of the Law, a Government Regulation may be established even though the provisions of the Law do not explicitly require it.

Government Regulations are the rules that make the provisions of a law work and be enforced. "A new Government Regulation can be formed if there is already a law, but a government regulation can be formed even though the law is not explicitly stipulated so that it is further regulated in a Government Regulation"19.

The preparation of regulations for the formation of legislation is part of the building of positive Indonesian law which has an important role in the building of national law. According to Bagir Manan, in addition to containing elements that are currently in force, there are other elements, namely (a) binding in general and in particular; (b) enforced through government or courts; and (c) apply and enforce in Indonesia ${ }^{20}$.

In the preparation of Government Regulations, the principles of the formation of laws and regulations should be kept in mind, including: clarity of purpose; the appropriate forming institution or official; suitability between types, hierarchies, and payload materials; can be implemented; usability and effectiveness; clarity of formulation; and openness ${ }^{21}$. One of the most important principles in the preparation of Government Regulations is the principle of proper institutional or official formation. In this principle, each type of legislation must be made by the authorized law-making institution/official. These laws and regulations can be canceled or null and void if they are made by an unauthorized institution/official ${ }^{22}$.

Because it is projected that the material regulated in this regulation on the implementation of coercive measures will involve the implementation of forced executions and administrative sanctions against the decisions of the Administrative Court, the appropriate agency/institution to be the initiator is the Supreme Court of the Republic of Indonesia.

\section{Closing}

From the description above, it can be concluded that the establishment of the State Administrative Court is intended to resolve disputes between the government and citizens. With the existence of the State Administrative Court or

18 A. Hamid S Attamimi, Pembentukan Undang-undang Indonesia: Beberapa Catatan yang Memerlukan Perhatian, Makalah disampaikan pada seminar Keuangan Negara di Bepeka, Jakarta, March 18, 1989.

19 Maria Farida Indrati S. SH., MH., Ilmu Perundang Undangan, Dasar-dasar dan Pembentukannya, Kanisius, Jakarta, 2002.

${ }^{20}$ Bagir Manan, Hukum Positif Indonesia (Yogyakarta: FH UII Pers, 2004), p. 1-30.

${ }^{21}$ Article 5 of Act No. 12 of 2011 concerning the Establishment of Legislation.

22 Rosyid Al Atok, Konsep Pembentukan Peraturan Perundang-Undangan Teori, Sejarah, Dan Perbandingan Dengan Beberapa Negara Bikameral, Ed. Revision, Setara Press, Malang, 2015, p. 28. 
the so-called PTUN which provides protection to the people with guarantees that can be obtained in accordance with the provisions of the legislation. This provision regarding the State Administrative Court is regulated in Act No. 5 of 1986 concerning the State Administrative Court, which was later amended by Act No. 9 of 2004 concerning Amendments to Act No. 5 of 1986 concerning the State Administrative Court, and last amended by Act No. 51 of 2009 concerning the second amendment of Act No. 5 of 1986 concerning the State Administrative Court. However, until now there has been no Implementing Regulation of the Administrative Court Law, thus creating a legal vacuum. Therefore, it is necessary to establish implementing regulations of the PTUN Law so that it can provide legal certainty for the community, as a guarantor of legal certainty as a general principle of proper governance, namely a state of law that prioritizes the basis of legislation, propriety and justice in every policy of state administrators and what is also important is to maintain the dignity and/or authority of the State Administrative Court. In the formation of implementing regulations of the PTUN Act, the author provides suggestions and input for implementing regulations in the form of Government Regulations. This idea is based on the theory and hierarchy of laws and regulations. According to Act No. 12 of 2011 concerning the Establishment of Legislations, the content of the Government Regulation contains material to carry out the Act as it should. So the author feels it is appropriate that the implementing regulations of the PTUN Act are in the form of Government Regulations. In the formation of the Government Regulation, it is also necessary to pay attention to the technique of its formation. The formation technique referred to must be based on Act No. 12 of 2011 concerning the Establishment of Legislation.

\section{References}

\section{Journal}

[1] Alvi Syahri. Penegakan Hukum Terhadap Kebijakan Yang Melanggar Kode Etik. Jurnal Daulat Hukum Unissula. Volume 3 Issue 3, 2020, p. 6.

[2] Hasto Sasmito, Implementation Of Decisions And Obstacles Administrative Court Implementation Obstacles, Jurnal Daulat Hukum Unissula, Vol. 1. No. 2 June 2018, p. 2.

[3] Jawade Hafidz, Malfungsi Han Dan Upaya Melakukan Rekonstruksi Sistem Hukum Yang Ada Menuju Hukum Yang Melayani. Jurnal Hukum Unissula, Vol. XXVIII, No.2 December 2012, p. 9.

\section{Book}

a. Hamid S Attamimi, Pembentukan Undang-undang Indonesia: Beberapa Catatan yang Memerlukan Perhatian, Makalah disampaikan pada seminar Keuangan Negara di Bepeka, Jakarta, March 18, 1989.

[2] Bagir Manan, Hukum Positif Indonesia (Yogyakarta: FH UII Pers, 2004)

[3] Bayu Dwi Anggono, Perkembangan Pembentukan Undang-Undang di Indonesia (Jakarta: Konstitusi Pers, 2014). Bayu Dwi Anggono quotes Achmad Ali's writings in his book Menguak Teori Hukum (Legal Theory) dam Teori Peradilan (Judicial prudence), 2009 
[4] Jimly Asshiddiqie, Perihal Undang-Undang, Ed.1, Konstitusi Press, Jakarta, 2006

[5] Jimly Asshidiqie, Pengantar Ilmu Hukum Tata Negara (Jilid 1), Sekretariat Jenderal dan Kepaniteraan MK RI, Jakarta, 2006

[6] M. Yahya Harahap, Ruang Lingkup Permasalahan Eksekusi Bidang Perdata, Sinar Grafika, Second Edition, Fourth Printing, Jakarta, 2009

[7] Maria Farida Indrati S. SH., MH., Ilmu Perundang Undangan, Dasar-dasar dan Pembentukannya, Kanisius, Jakarta, 2002.

[8] Maria Farida Indrati Soeprapto, Ilmu Perundang-Undangan: Jenis, Fungsi, dan Materi Muatan . (Yogyakarta: Kanisius), 2007

[9] Ridwan Hr, Hukum Administrasi Negara, Raja Grafindo Persada, Jakarta: 2007

[10] Ronny Haniatjo Soemitro, Metode Penelitian Hukum dan Jurumetri, (Jakarta: PT Ghalia Indonesia, 1990)

[11] Rosyid Al Atok, Konsep Pembentukan Peraturan Perundang-Undangan Teori, Sejarah, Dan Perbandingan Dengan Beberapa Negara Bikameral, Ed. Revision, Setara Press, Malang, 2015

\section{Regulation}

[1] Act No. 5 of 1986 concerning the State Administrative Court.

[2] Act No. 51 of 2009 concerning the Second Amendment to Act No. 5 of 1986 concerning the State Administrative Court.

[3] Act No. 12 of 2011 concerning the Establishment of Legislation.

\section{Internet}

[1] Sucipto, Purnomo. Mengapa Undang-Undang perlu peraturan pelaksana. https://setkab.go.id/mengapa-undang-undang-perlu-peraturanpelaksanaan/. 11 March 2015. Retrieved 01 July 2021. 